\title{
Cigarette Smoke and Estrogen Signaling in Human Airway Smooth Muscle
}

\author{
Venkatachalem Sathish ${ }^{\mathrm{a}, \mathrm{b}}$ Michelle R. Freeman ${ }^{\mathrm{a}}$ Emma Long ${ }^{\mathrm{a}}$ \\ Michael A. Thompson ${ }^{a, b}$ Christina M. Pabelick ${ }^{a, b} \quad$ Y.S. Prakash ${ }^{a, b}$
}

aDepartments of Anesthesiology and bPhysiology \& Biomedical Engineering, Mayo Clinic, Rochester, MN USA

\section{Key Words}

Sex Steroid • Lung • Secondhand Smoke • Bronchoconstriction • Bronchodilation • Estrogen Receptor • Calcium Regulation • Store operated calcium entry • STIM1

\begin{abstract}
Aims: Cigarette smoke (CS) in active smokers and second-hand smoke exposure exacerbate respiratory disorders such as asthma and chronic bronchitis. While women are known to experience a more asthmatic response to CS than emphysema in men, there is limited information on the mechanisms of CS-induced airway dysfunction. We hypothesize that CS interferes with a normal (protective) bronchodilatory role of estrogens, thus worsening airway contractility. Methods: We tested effects of cigarette smoke extract (CSE) on $17 \beta$-estradiol $\left(E_{2}\right)$ signaling in enzymatically-dissociated bronchial airway smooth muscle (ASM) obtained from lung samples of non-smoking female patients undergoing thoracic surgery. Results: In fura-2 loaded ASM cells, CSE increased intracellular calcium ([Ca $\left.\left.{ }^{2+}\right]_{\mathrm{i}}\right)$ responses to $10 \mu \mathrm{M}$ histamine. Acute exposure to physiological concentrations of $\mathrm{E}_{2}$ decreased $\left[\mathrm{Ca}^{2+}\right]_{\mathrm{i}}$ responses. However, in $24 \mathrm{~h}$ exposed CSE cells, although expression of estrogen receptors was increased, the effect of $\mathrm{E}_{2}$ on $\left[\mathrm{Ca}^{2+}\right]_{i}$ was blunted. Acute $\mathrm{E}_{2}$ exposure also decreased store-operated $\mathrm{Ca}^{2+}$ entry and inhibited stromal interaction molecule 1 (STIM1) phosphorylation: effects blunted by CSE. Acute exposure to $\mathrm{E}_{2}$ increased CAMP, but less so in $24 \mathrm{~h}$ CSE-exposed cells. 24h CSE exposure increased S-nitrosylation of ER $\alpha$. Furthermore, 24h CSE-exposed bronchial rings showed increased bronchoconstrictor agonist responses that were not reduced as effectively by $E_{2}$ compared to non-CSE controls. Conclusion: These data suggest that CS induces dysregulation of estrogen signaling in ASM, which could contribute to increased airway contractility in women exposed to CS
\end{abstract}

Copyright $@ 2015$ S. Karger AG, Basel

Sathish Venkatachalem, $\mathrm{PhD}$,

Assistant Professor of Physiology

\section{KARGER 125}

Department of Anesthesiology, Mayo Clinic

Rochester, MN 55905 (USA)

Tel. +1 507255 8073, Fax +1 507255 7300, E-Mail venkatachalem.sathish@mayo.edu 


\section{Cellular Physiology Cell Physiol Biochem 2015;36:1101-1115 \begin{tabular}{l|l|l}
\hline DOI: 10.1159/000430282 & (C) 2015 S. Karger AG, Basel
\end{tabular} \begin{tabular}{l|l|} 
and Biochemistry Published online: June 25, 2015 & www.karger.com/cpb \\
\cline { 1 - 2 }
\end{tabular} \\ Sathish et al.: Estrogens, Cigarette Smoke, and Airways}

\section{Introduction}

Exposure to cigarette smoke (CS) increases the incidence of airway diseases such as asthma and bronchitis. Lower airway mucosal inflammation and bronchial hyperreactivity occur commonly not only in smokers, but also following secondhand smoke (SHS) exposure $[1,2]$. Here, lungs of adolescent girls may be more vulnerable to the effects of smoking [3]. Studies also suggest that $30 \%$ of women smoke during their reproductive years in the United States and others are highly susceptible to SHS [4]. Interestingly, unlike men who tend to show emphysematous changes in their lungs, women experience more asthmatic symptoms with CS, suggesting effects on the conducting airways [5]. However, the underlying mechanisms are not known.

There is increasing recognition that lung function is modulated by sex steroids, particularly estrogens [6-10], and that sex steroids may play a role in diseases such as asthma, COPD and pulmonary fibrosis. Accordingly, a relevant question is whether and how CS interacts with estrogen signaling in airways of females to affect airway contractility. Estrogen effects are mostly mediated via ER $\alpha$ or ER $\beta$, and both receptors are present in the ASM [11]. Estrogen regulates multiple cellular functions in a variety of cell types in the lung. Here we are focusing on airway smooth muscle (ASM) cells, given their role in contractility, and evidence that this cell type is frequently affected by CS exposure [12-14]. While the mechanisms by which sex steroid action in the airway are still under exploration $[6-8,10]$, there is now evidence that as in the vasculature, estrogens can induce bronchodilation, by reducing intracellular $\mathrm{Ca}^{2+}\left(\left[\mathrm{Ca}^{2+}\right]_{\mathrm{i}}\right)$ in ASM $[6,7]$. Accordingly, we explored the hypothesis that CS detrimentally influences estrogen signaling in ASM.

ASM contractility and relaxation determines airway tone by maintaining bronchoconstriction and bronchodilation. $\left[\mathrm{Ca}^{2+}\right]_{\mathrm{i}}$ responses to bronchoconstrictor agonist involve sarcoplasmic reticulum (SR) $\mathrm{Ca}^{2+}$ release as well as $\mathrm{Ca}^{2+}$ influx [15-17], with the latter occurring via voltage-gated or receptor-operated channels, or due to SOCE following SR $\mathrm{Ca}^{2+}$ depletion [18-21]. Our previous studies demonstrated that in human ASM, functional estrogen receptors (ERs) exist and that estrogens acutely (i.e. non-genomically) reduce agonistinduced $\left[\mathrm{Ca}^{2+}\right]_{\mathrm{i}}$ levels [6], by potentially enhancing cAMP signaling [7]. We hypothesize that dysregulation of estrogen signaling by CS results in the loss of an important bronchodilatory component, contributing to smoking-related diseases. To test this hypothesis, we have used human ASM cells to address: 1) Potential cigarette smoke effects on altered estrogen $\left[\mathrm{Ca}^{2+}\right]_{\mathrm{i}}$ regulation, which plays an important role in airway tone; and 2) CS extract (CSE) effect of specific ER expression and function.

\section{Materials and Methods}

\section{Materials}

DMEM/F-12, fetal bovine serum, Hanks Balanced Salt Solution (HBSS), and Fura-2 AM were purchased from Life Technologies (Carlsbad, CA); ER $\alpha$ (ab2746 1:1000 dilution) stromal interaction molecule 1 (STIM1; ab62031, 1:1000 dilution), Phosphoserine (ab17465, 1:1000 dilution), S-nitrosocysteine (ab50185, 1:1000 dilution) and TMEM66 (ab154538, 1:1000 dilution) primary antibodies from Abcam (Cambridge, MA); ERß(MA1-81281, 1:500 dilution)antibody from ThermoFisher Scientific (Waltham, MA); calcium releaseactivated calcium modulator 1 (Orai1; ACC-060, 1:1000 dilution) primary antibody from Alomone labs (Israel); Protein A/G plus agarose were from Santa Cruz Biotechnology (Santa Cruz, CA). (R,R)-5, 11-diethyl5,6,11,12-tetrahydro-2,8-chrysenediol [(R,R)-THC] and diarylpropionitrile (DPN) were from Tocris Biosciences (Ellisville, MO). All other reagents and chemicals were purchased from Sigma (St. Louis, MO) unless otherwise specified.

Under a Mayo IRB-approved protocol, human bronchi (3rd generation or higher) were obtained from lung resection samples incidental to patient thoracic surgery at Mayo Clinic for focal tumors (bronchoalveolar 


\section{Cellular Physiology Cell Physiol Biochem 2015;36:1101-1115 \begin{tabular}{|l|l|}
\hline DOI: 10.1159/000430282 & (c) 2015 S. Karger AG, Basel
\end{tabular} \begin{tabular}{l|l} 
and Biochemistry Published online: June 25, 2015 & www.karger.com/cpb
\end{tabular} \\ Sathish et al.: Estrogens, Cigarette Smoke, and Airways}

carcinoma and infections were excluded) only samples from normal areas of the lung (identified by the pathologist) were utilized. While patient identifiers are not retained with the samples, medical histories are used to select samples from female non-smokers without other significant chronic airway disease such as asthma.

ASM cells were isolated and cultured using previously established procedures [13, 22-25]. Briefly, smooth muscle from lung tissues was dissected after the epithelium was removed by mild abrasions. The tissue was minced in ice cold Hanks' balanced salt solution (HBSS) containing $2 \mathrm{mM} \mathrm{Ca}^{2+}$ and ASM cells isolated using papain/collagenase digestion, separated by ovomucoid/albumin gradient centrifugation, and resuspended in DMEM/F12 medium with 10\% fetal bovine serum (FBS). Cells were plated and maintained in 10\% FBS DMEM/F12 media at $37^{\circ} \mathrm{C}\left(5 \% \mathrm{CO}_{2}, 95 \%\right.$ air $)$ until $80 \%$ confluent and then serum deprived in DMEM/F-12 for $48 \mathrm{~h}$, to enter cells into a quiescent stage (maintaining contractile phenotype and receptor expression). Experiments were performed in cells less than $3^{\text {rd }}$ passage. To verify phenotype stability, the presence of multiple smooth muscle markers such as $\alpha$-actin, myosin, calponin and caldesmon were confirmed periodically.

\section{CSE Preparation}

CSE solution was prepared by modified method of Blue and Janoff [26] and freshly prepared for each experiment with reference cigarettes of standardized composition (U of Kentucky). Briefly, cigarette smoke ( 1 cigarette to $1 \mathrm{~cm}$ butt length/10 ml medium) was drawn into a $60 \mathrm{ml}$ syringe and then slowly bubbled through the medium. Following CSE preparation, pH corrected (7.4), then the solution was filtered (0.2 $\mu \mathrm{m})$ and used for cell treatment $[13,27]$.

\section{$\left[\mathrm{Ca}^{2+}\right]_{i}$ imaging}

$\left[\mathrm{Ca}^{2+}\right]_{\mathrm{i}}$ imaging of human ASM has been previously described [13, 23-25]. In 8-well borosilicate coverglass chambers, human ASM cells were incubated with $5 \mu \mathrm{M}$ fura-2/AM for $45 \mathrm{~min}$ at room temperature, washed, mounted on the microscope stage and perfused with HBSS. Cells (15-30/field) were imaged in real time using a Nikon Eclipse TE2000-U fluorescent microscope and imaging system software (MetaFluor; Universal Imaging, Downingtown, PA). Baseline $\left[\mathrm{Ca}^{2+}\right]_{\mathrm{i}}$ and responses to agonist were recorded.

\section{Western Blot Analysis}

Standard procedures were followed. Proteins were separated by SDS-PAGE using a Criterion Gel System (4-15\% gradient; Bio-Rad, Hercules, CA) and transferred to nitrocellulose membranes. After blocking, appropriate primary and secondary antibodies were applied. Protein bands and relative densities were measured using either chemiluminescence substrate (Pierce Chemical Co., Rockford, IL) or farred fluorescence imaging (Li-Cor Odyssey imaging system). For STIM1 phosphorylation studies, after treatment with cyclopiazonic acid $(10 \mu \mathrm{M}, \mathrm{CPA})$ for $5 \mathrm{~min}$, cells were harvested and lysed using RIPA buffer (ThermoFisher Scientific) supplemented with protease inhibitor cocktail (Roche diagnostics). Cells were further disrupted by sonication for $10 \mathrm{~s}$ in ice cold conditions followed by centrifuging at 10,000 $\mathrm{xg}$ for 10 $\min$ at $4^{\circ} \mathrm{C}$. Collected supernatant was then used for standard immunoprecipitation protocol [28] . Briefly, BSA-treated A/G plus agarose was added to $100 \mu \mathrm{g}$ protein of cell lysates and was rotated for $30 \mathrm{~min}$ at $4^{\circ} \mathrm{C}$. Centrifugation was used to remove nonspecific proteins bound to the A/G plus agarose; the remaining supernatant was used for immunoprecipitation. Supernatant sample was combined with anti-STIM1 (1 $\mu \mathrm{g})$ and $50 \mu \mathrm{L} \mathrm{A} / \mathrm{G}$ agarose complex, and rotated overnight at $4^{\circ} \mathrm{C}$. Following incubation, lysate-complexes were pelleted using centrifugation and washed four times with cold washing buffer (20mM HEPES 7.4 pH, 150 $\mathrm{nM} \mathrm{NaCl}, 1 \mathrm{mM}$ EDTA, $0.5 \%$ Tween20). Pellets were resuspended in $50 \mu \mathrm{L}$ of sample buffer and proteins were separated using standard SDS-Page. Proteins were transferred to a nitrocellulose membrane, and immunoblotted with primary anti-phospho-serine antibody. In parallel, $25 \mu \mathrm{g}$ of cell lysate from the same sample was subjected to SDS-PAGE and immunoblotted for input protein controls [29].

\section{CAMP ELISA}

Human ASM cells were grown to confluence in $100 \mathrm{~mm}$ plates, treated with CSE for $24 \mathrm{~h}$ and then washed with HBSS. Cells were then exposed to agonist in the presence of $0.5 \mathrm{mM}$ IBMX for $15 \mathrm{~min}$. After treatment, cells were scraped and lysed in the presence of protease inhibitor cocktail (Roche Life sciences). cAMP levels in whole cell lysate were determined by competitive-binding enzyme immunoassay (Cell Bio 


\section{Cellular Physiology Cell Physiol Biochem 2015;36:1101-1115 \begin{tabular}{l|l|l}
\hline DOI: 10.1159/000430282 & C) 2015 S. Karger AG, Basel
\end{tabular} and Biochemistry Published online: June 25, $2015 \quad$ www.karger.com/cpb

Labs, San Diego, CA,) per manufacturer's protocol. Absorbance was measured using a Molecular Devices Flexstation 3 (Sunnyvale, CA).

\section{Immunodetection of S-Nitrosocysteine}

Human ASM cells were exposed to CSE for $24 \mathrm{~h}$, washed with HBSS and harvested using cell lysis buffer in the presence of protease inhibitors. Equal amount of total protein (100 $\mu \mathrm{g})$ from each sample was immunoprecipitated overnight by using anti-ER $\alpha$ antibody $(1 \mu \mathrm{g})$ and A/G agarose $(50 \mu \mathrm{L})$. Following immunoprecipitation (as described above), samples were resolved by SDS-PAGE and immunodetected using an anti-S-nitrosocysteine antibody by standard protocols. Input control was performed using the same cell lysate for protein normalization.

\section{Force studies}

Bronchial rings $\left(4^{\text {th }}-6^{\text {th }}\right.$ generation) isolated from human lung were epithelium denuded by gentle abration and used for force contractile studies as described previously [13, 25]. Briefly, experiments were conducted in physiological salt solution (PSS) bubbled with $95 \% \mathrm{O}_{2}$ and $5 \% \mathrm{CO}_{2}\left(37^{\circ} \mathrm{C}\right)$. Bronchial rings were then stretched to optimal length using $1 \mu \mathrm{M}$ acetylcholine (ACh). At this length, samples were incubated with $2 \%$ CSE for $24 \mathrm{~h}$. Time control samples were exposed to vehicle only for the same period. Rings were contracted again with $1 \mu \mathrm{M}$ ACh in the presence or absence of $E_{2}$ (20 min incubation prior to contraction). Data were obtained using a custom-built software program (LabView, National Instruments, 1Hz).

\section{Statistical analysis}

Bronchial samples from 5 different female patients were used to obtain ASM cells. Each protocol was repeated at least 2 times, although not all protocols were performed in the same samples. Results were compared using one way ANOVA with Student-Newman-Keuls or Dunnet's post hoc analysis. N represents the number of patient samples. Statistical significance was established at $p<0.05$. All values are expressed as mean \pm SE.

\section{Results}

CSE effects on $\left[\mathrm{Ca}^{2+}\right]_{i}$ responses to estrogen

In fura-2 loaded human ASM cells, $24 \mathrm{~h}$ exposure to $1 \%$ or $2 \%$ CSE significantly increased peak and plateau $\left[\mathrm{Ca}^{2+}\right]_{\mathrm{i}}$ responses to $10 \mu \mathrm{M}$ histamine, in comparison to vehicle not treated with CSE: effects comparable to our previous reports $[13,27]$. In a separate set of cells, acute exposure (20 min) to physiologically-relevant concentration of $1 \mathrm{nM} \mathrm{E}_{2}$ significantly decreased $\left[\mathrm{Ca}^{2+}\right]_{\mathrm{i}}$ responses to histamine. We had previously shown that such effects lead to bronchodilation $[6,7]$. In $1 \%$ or $2 \%$ CSE-exposed ASM cells, the reducing effect of $E_{2}$ on $\left[\mathrm{Ca}^{2+}\right]_{\mathrm{i}}$ was blunted relative to non-CSE vehicle (Fig. 1).

\section{CSE increases estrogen receptor expression}

We had previously found that estrogen effects on $\left[\mathrm{Ca}^{2+}\right]_{i}$ were dependent on estrogen receptors (ER $\alpha$ and $E R \beta)[6,7]$. In the samples of the present study, we confirmed that human ASM expressed both ER $\alpha$ and ER $\beta$ (Fig. 2). Based on the results obtained in Figure 1 (blunted $\mathrm{E}_{2}$ mediated $\left[\mathrm{Ca}^{2+}\right]_{\mathrm{i}}$ responses), we expected CSE to reduce ER expression. However, exposure to CSE $(1 \%$ or $2 \%, 24 \mathrm{~h})$ significantly increased ER $\alpha$ and E R $\beta$ expression (Fig. 2), raising the question of whether CSE induced ER dysfunction.

\section{CSE increases $\left[\mathrm{Ca}^{2+}\right]_{i}$ responses to ER isoform-specific agonists}

Since expression of both ERs increased with $24 \mathrm{~h}$ CSE, we next investigated which receptor was functionally involved in CSE vs. acute effects on $\left[\mathrm{Ca}^{2+}\right]_{\mathrm{i}}$ regulation. We used specific agonists for $\mathrm{ER} \alpha$ (THC), ER $\beta$ (DPN) and followed the procedure as in Figure 1, where instead of $E_{2}$, THC or DPN (10 nM) were used. Acute effects on $\left[\mathrm{Ca}^{2+}\right]_{\mathrm{i}}$ were mediated largely by a ER $\alpha$ agonist but not by a ER $\beta$ agonist (Fig. 3). With 24h CSE exposure, the acute effect of THC on reducing $\left[\mathrm{Ca}^{2+}\right]_{\mathrm{i}}$ responses to histamine was absent (Fig. 3). 
Fig. 1. In fura-2 loaded human ASM cells, Cigarette smoke extract (CSE) exposure enhanced $\left[\mathrm{Ca}^{2+}\right]_{i}$ responses to agonist (10 $\mu \mathrm{M}$ histamine, top panel). Acute exposure to physiological concentrations of $\mathrm{E}_{2}$ decreased the amplitude of $\left[\mathrm{Ca}^{2+}\right]_{\mathrm{i}}$ responses to histamine in both $1 \%$ and 2\% CSE-exposed ASM cells, the effect of $\mathrm{E}_{2}$ on $\left[\mathrm{Ca}^{2+}\right]_{\mathrm{i}}$ was blunted relative to vehicle ( $\mathrm{A}$ and $\mathrm{B}$ ). The percentage change of amplitude $\left[\mathrm{Ca}^{2+}\right]_{1}$ response by $\mathrm{E}_{2}$ and CSE is represented in panel $\mathrm{C}$. There was no statistical difference between effects of the two CSE concentrations. Values represented as means $\pm \mathrm{SE}(\mathrm{n}=5)$, \# indicates significant $\mathrm{E}_{2}$ effect compared to vehicle, *indicates significant CSE effect compared to vehicle $(P<0.05)$.

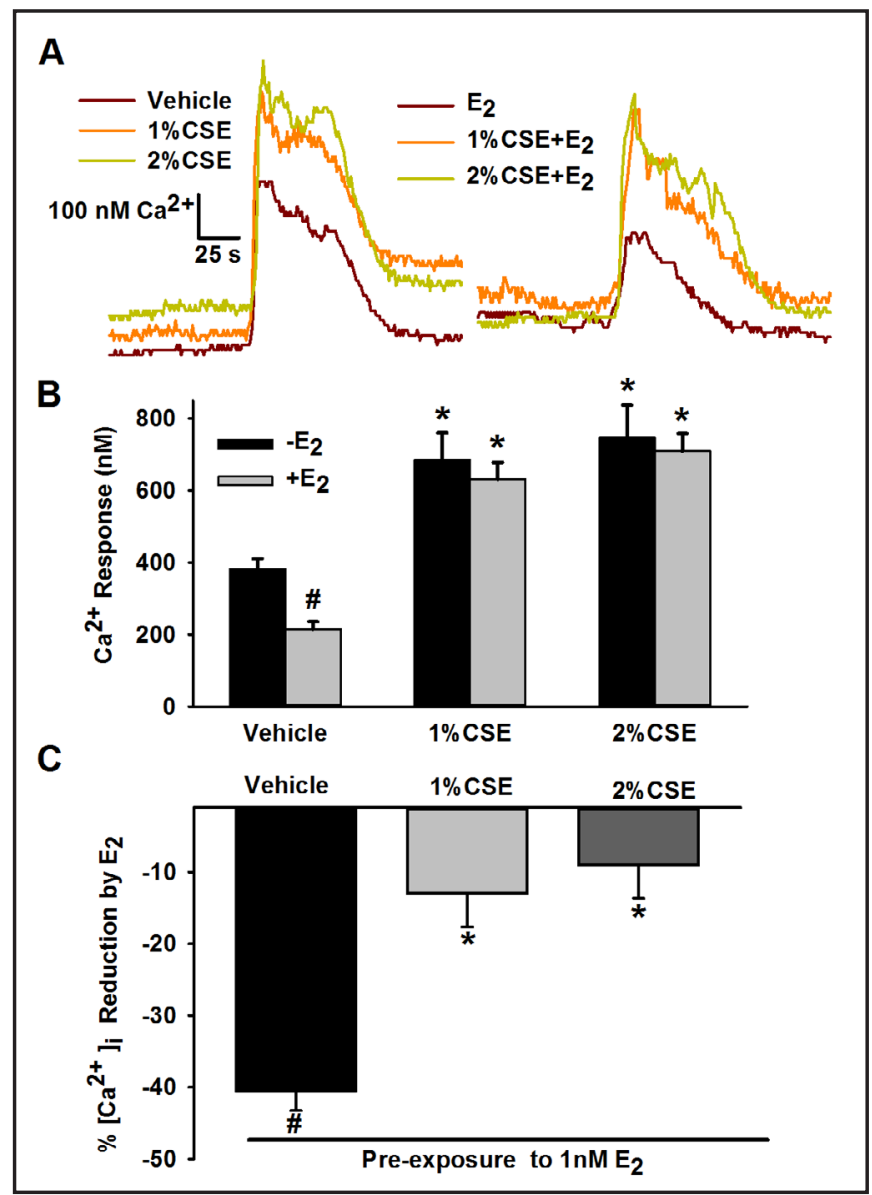

Fig. 2. Human ASM expresses both estrogen receptor $\mathrm{ER} \alpha$ and ER $\beta$. Human ASM cells exposed to $24 \mathrm{~h} \mathrm{CSE}(1 \%$ and $2 \%)$ significantly increased ER $\alpha$ and ER $\beta$ receptor expression. Here GAPDH served as a loading control. Values represented as means $\pm \mathrm{SE}$ $(\mathrm{n}=6)$. *indicates significant CSE effect compared to vehicle $(P<0.05)$.

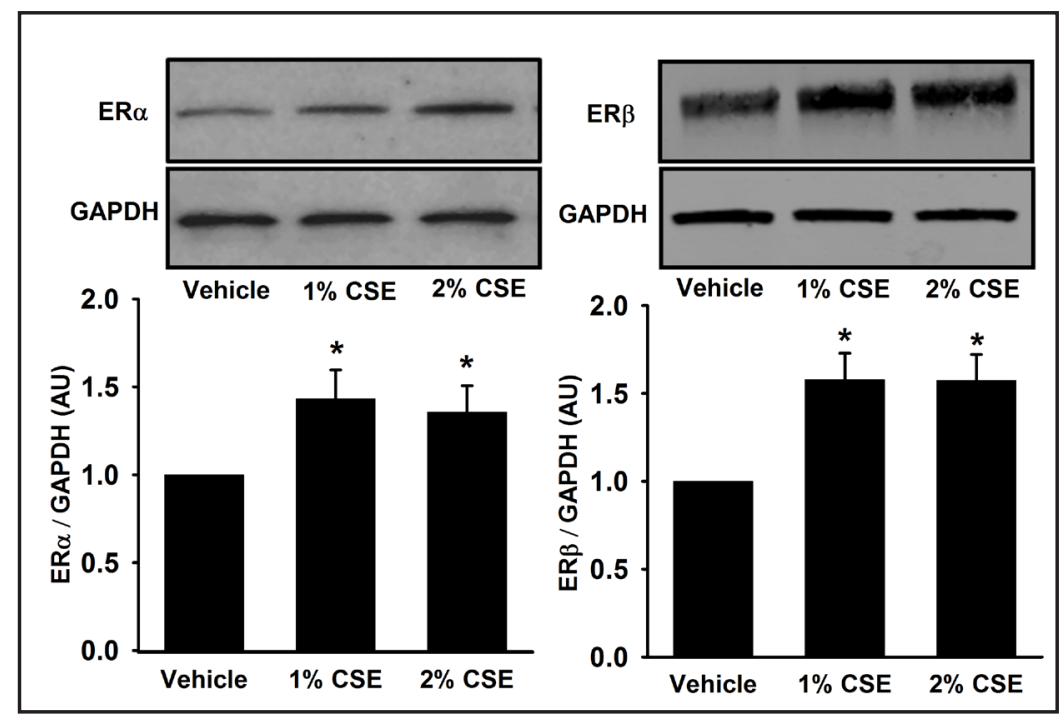

CSE blunts estrogen-induced reduction of store-operated Ca ${ }^{2+}$ entry (SOCE)

Previous studies in different cell types have shown that estrogens can inhibit $\mathrm{Ca}^{2+}$ influx [30-34]. We have previously shown that store-operated $\mathrm{Ca}^{2+}$ entry is a major influx mechanism in ASM $[19,35,36]$ and that estrogens can blunt SOCE in human ASM cells [6]. The effects of CSE per se on SOCE or their regulatory mechanisms are largely unknown. Exposure to CSE (24h) significantly increased SOCE responses in comparison to vehicle. $\mathrm{E}_{2}$ significantly decreased SOCE-mediated $\mathrm{Ca}^{2+}$ influx compared to vehicle (Fig. 4). However, 24h CSE exposure blunted the inhibitory $\mathrm{Ca}^{2+}$ influx effect of $\mathrm{E}_{2}$ on SOCE (Fig. 4). 
Fig. 3. Effect of CSE on $\left[\mathrm{Ca}^{2+}\right]_{\mathrm{i}}$ responses to ER isoform-specific agonists. In fura-2 loaded human ASM cells, acute exposure to isoform-specific agonists for $\mathrm{ER} \alpha$ and $\mathrm{ER} \beta$ yields a reduction in $\left[\mathrm{Ca}^{2+}\right]_{\mathrm{i}}$ response to histamine $(10 \mu \mathrm{M})$ that was mediated largely by ER $\alpha$ (activated using THC) but not ER $\beta$ (activated using DPN). With 24h CSE (both $1 \%$ and $2 \%$ ) exposure the acute effect of THC on reducing $\left[\mathrm{Ca}^{2+}\right]$ responses to histamine was absent. Values represented as means \pm SE $(n=4)$. *indicates significant CSE effect compared to vehicle, $\%$ indicates significant THC effect compared to vehicle $(P<0.05)$.

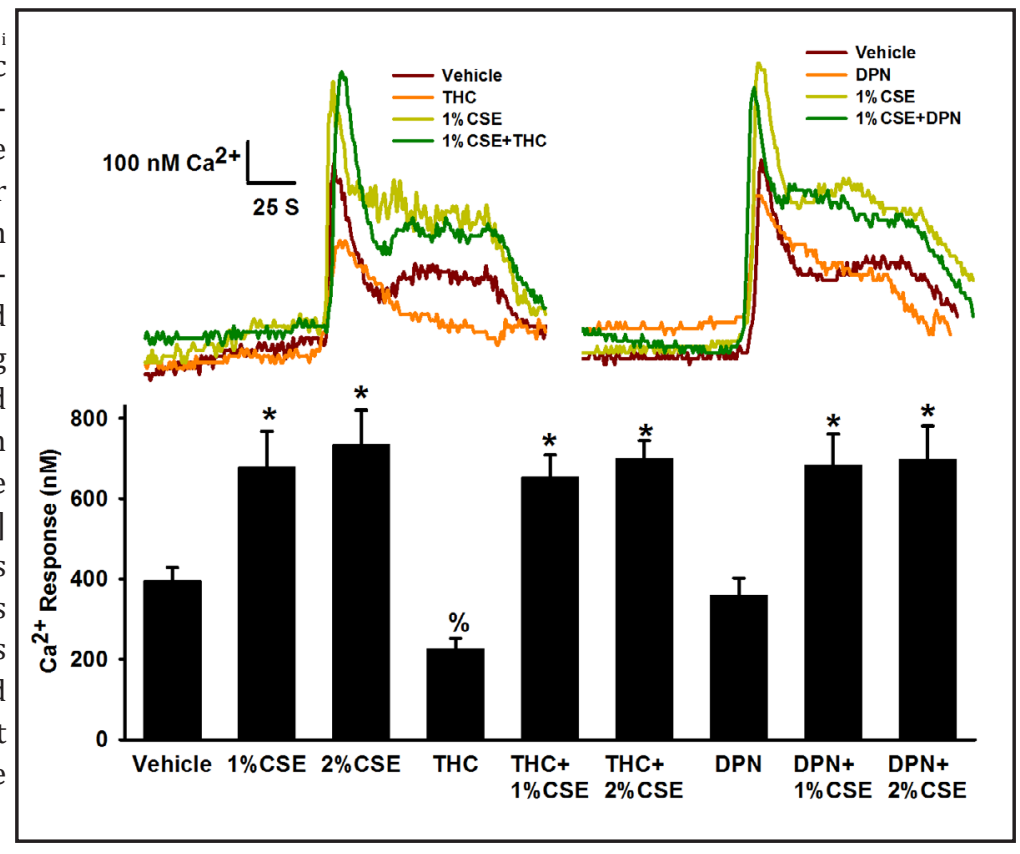

Fig. 4. Effect of CSE on estrogen-induced reduction of store-operated $\mathrm{Ca}^{2+}$ entry (SOCE). In human ASM cells, $24 \mathrm{~h}$ exposure to CSE significantly increased SOCE response in comparison to vehicle alone. Exposure to $\mathrm{E}_{2}$ (15 min) significantly decreased SOCE-mediated $\mathrm{Ca}^{2+}$ influx compared to vehicle. However, 24h CSE exposure blunted the effects of $\mathrm{E}_{2}$ on SOCE Values represented as means $\pm S E(n=5)$. \# indicates significant $E_{2}$ effect compared to vehicle, ${ }^{*}$ indicates significant CSE effect compared to vehicle $(P<0.05)$.

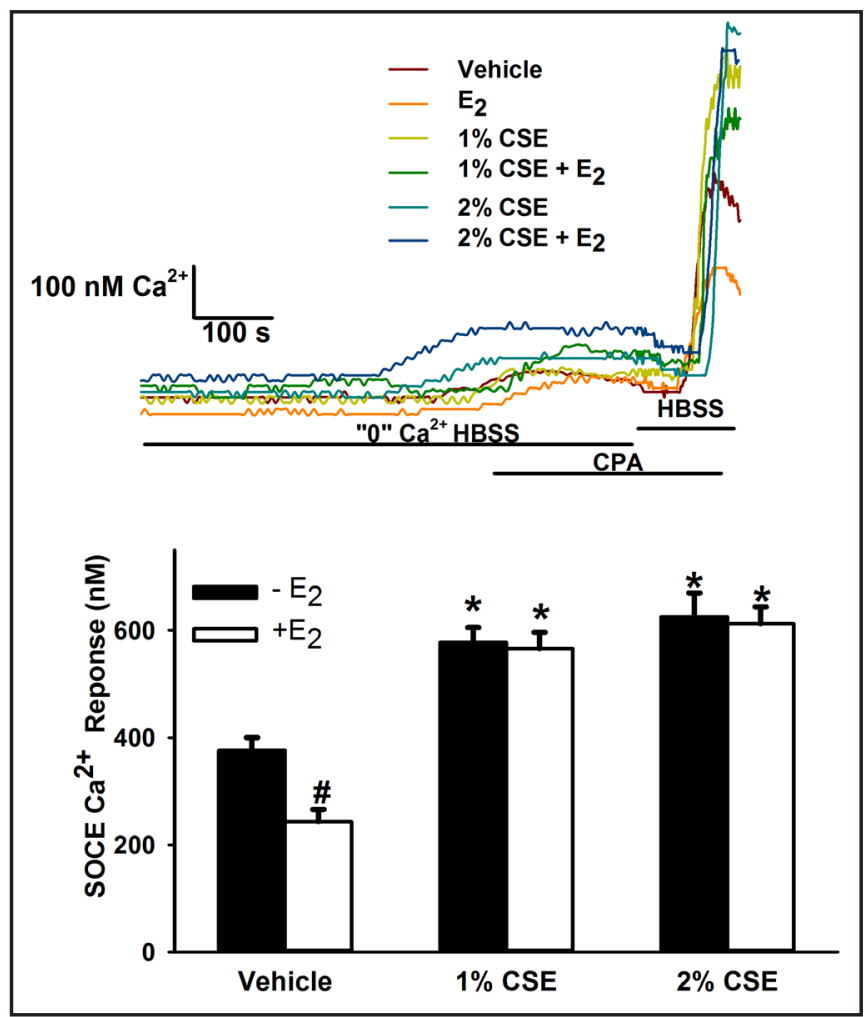

Western blot analysis of lysates from human ASM cells exposed $24 \mathrm{~h}$ to $1 \%$ or $2 \%$ CSE showed a significant increase in the SOCE regulatory proteins STIM1 and Orai1 compared to vehicle (Fig. 5). Additionally, we found expression of the newly-identified protein SARAF (SOCE-associated regulatory factor previously known as TMEM66), a negative regulator of STIM1/SOCE [37, 38]. With CSE exposure, SARAF expression remained unchanged, while the SARAF/STIM1 ratio was substantially reduced (Fig. 5B, D) which may explain the significantly increased SOCE following CSE exposure (Fig. 4). In a subset of studies, freshly isolated human ASM tissues were exposed $24 \mathrm{~h}$ to $1 \%$ or $2 \%$ CSE. Similar to isolated human 
Fig. 5. CSE alters expression of SOCE regulatory proteins. Western blot analysis of cell lysates and tissue homogenates from human ASM exposed $24 \mathrm{~h}$ to $1 \%$ or $2 \%$ CSE showed significant increase in the SOCE $\mathrm{Ca}^{2+}$ regulatory proteins STIM1 and Orai1 compared to vehicle. Interestingly, no changes were observed in expression of SARAF, a negative regulator of SOCE, but the ratio of SARAF to STIM1 was significantly reduced with CSE. Values represented as means \pm SE $(n=4)$. *indicates significant CSE effect compared to vehicle $(P<0.05)$.

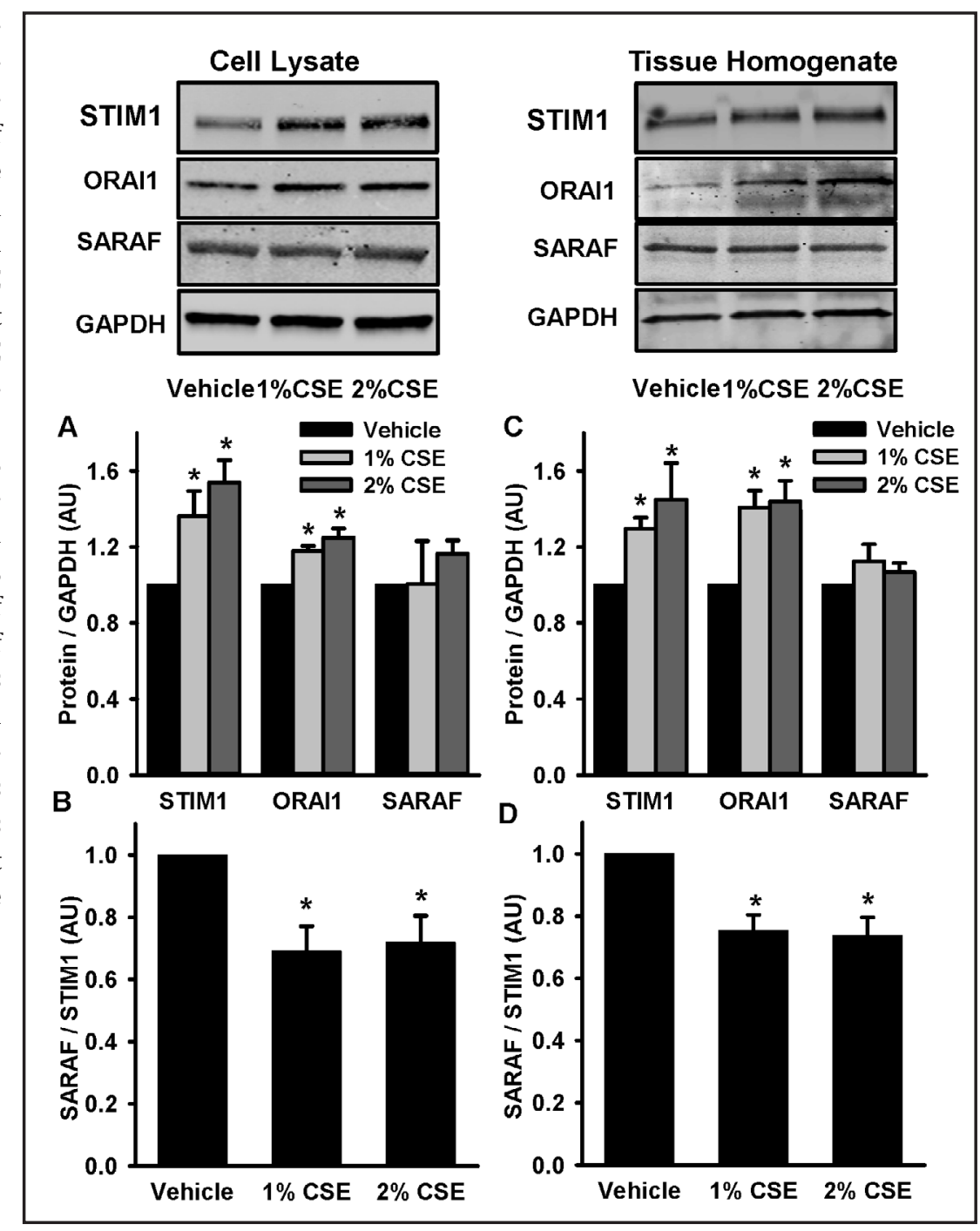

ASM cells, ASM tissues also showed significant increase in the expression of STIM1 and Orai1 (Fig. 5 C), confirming that the biochemical results were not an artifact of cell isolation and/ or culture.

Recent studies by Sheridan et al. [39] showed that estrogen acutely (non-genomic) inhibits phosphorylation and aggregation of STIM1, and thus reduces SOCE in bronchial epithelial cells. To explore whether similar mechanisms are present in human ASM, cells were incubated with CSE (24h) alone or in the presence of $\mathrm{E}_{2}(15 \mathrm{~min}$ acute exposure prior to addition of CPA), followed by treatment with CPA $(10 \mu \mathrm{M})$ for $5 \mathrm{~min}$. Cells were subjected to immunoprecipitation for STIM1, and then probed for phospho-serine (primary antibody recognizing proteins phosphorylated on multiple serine residues). Small aliquots of the cell lysate were used as an input control for total STIM1 and normalized with phospho-serine STIM1. $E_{2}$ exposure significantly reduced serine phosphorylation of STIM1. CSE exposure significantly increased the CPA activated STIM1 phosphorylation and prevented $\mathrm{E}_{2}$-mediated inhibitory effects on phosphorylation of STIM1 (Fig. 6).

We recently reported that estrogen acutely increases cAMP in human ASM cells thereby reducing $\left[\mathrm{Ca}^{2+}\right]_{\mathrm{i}}[7]$. To determine whether the blocking effect of CSE in human ASM cells occurs through interference with this mechanism, cAMP was measured using competitivebinding ELISA. CSE exposure $(24 \mathrm{~h})$ significantly decreased intracellular cAMP compared to vehicle. Acute exposure to $\mathrm{E}_{2}(15 \mathrm{~min})$ significantly increased cAMP in human ASM cells (Fig. 
Fig. 6. CSE alters STIM1 phosphorylation. Immunoprecipitation for phospho serine-STIM1 following activation of SOCE by CPA $(10 \mu \mathrm{M})$ was used as an index of STIM1 activation. Acute exposure to $\mathrm{E}_{2}$ significantly inhibited STIM1 phosphorylation while 2\% CSE significantly enhanced STIM1 phosphorylation. The $\mathrm{E}_{2}$ effect on inhibition of STIM1 phosphorylation was absent in 24h CSE-exposed human ASM cells, consistent with effects on SOCE in ASM cells. Aliquots of the cell lysates from the samples were used to detect input STIM1 and served as a loading control. Values represented as means \pm SE $(n=4)$. " indicates significant $\mathrm{E}_{2}$ effect compared to vehicle, *indicates significant CSE effect compared to vehicle and/or $\mathrm{E}_{2} \operatorname{group}(P<0.05)$.

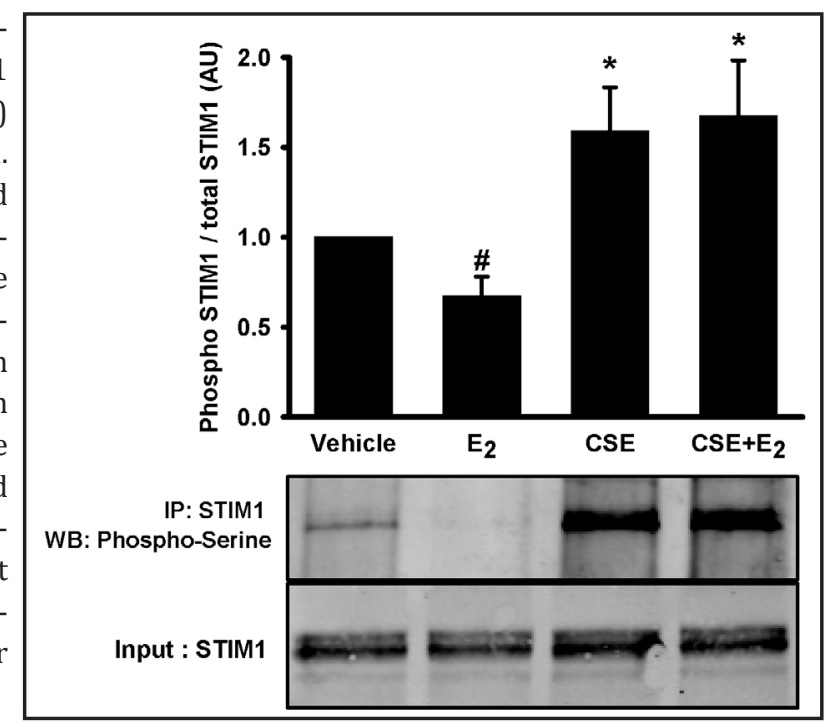

Fig. 7. Role of estrogen on cAMP levels. In human ASM cells, $24 \mathrm{~h}$ exposures to CSE significantly decreased intracellular cAMP compared to vehicle. Acute exposure to $\mathrm{E}_{2}(20 \mathrm{~min})$ significantly increased intracellular cAMP in human ASM cells compared to vehicle. CSE exposure significantly reduced the effects of $E_{2}$ on intracellular cAMP production. Values represented as means \pm SE $(n=4)$. *indicates significant CSE effect compared to vehicle, \#indicates significant $\mathrm{E}_{2}$ effect compared to vehicle, ${ }^{\circledR}$ indicates CSE $+\mathrm{E}_{2}$ effect compared to $\mathrm{E}_{2}$ treatment $(P<0.05)$.

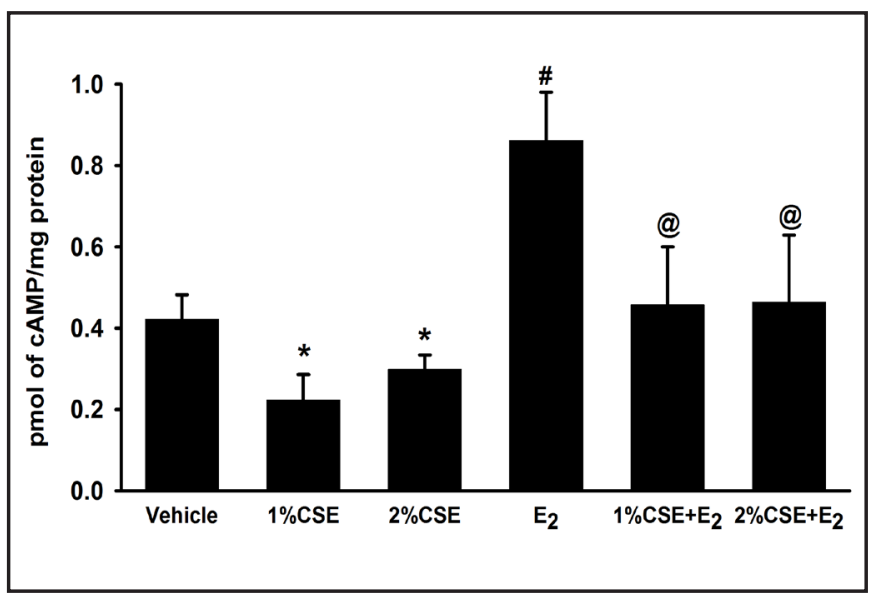

7). In CSE-exposed cells the effect of $\mathrm{E}_{2}$ on cAMP levels was significantly blunted, indicating the loss of an important mechanism for reducing $\left[\mathrm{Ca}^{2+}\right]_{i}$ by estrogen with CSE exposure.

\section{CSE increases S-nitrosylation of ER $\alpha$}

To decipher the mechanistic differences observed in the expression and function of ER $\alpha$ following CSE exposure, ER $\alpha$ nitrosylation was measured based on the idea that several components in CS have nitrosylating effects. A previous study by Garban et al. [40] demonstrated $S$-nitrosothiol modification of a cysteine residue within ERs resulting in a significant reduction of function. To measure nitrosothiol modification of ER $\alpha$ in ASM cells, ER $\alpha$ was immunoprecipitated and immunoblotted against $S$-nitrosocysteine. CSE $(1 \%$ or $2 \%$, $24 \mathrm{~h}$ ) exposure significantly increased S-nitrosocysteine following protein normalization to $\mathrm{ER} \alpha$ (Fig. 8), indicating increased nitrosothiol formation within ER $\alpha$.

\section{CSE blunts estrogen-induced reduction in ASM contractility}

Epithelium-denuded human bronchial rings stretched to optimal length produced the typical, sustained force responses to $1 \mu \mathrm{M}$ ACh. Acute exposure $\left(20 \mathrm{~min}\right.$ ) to $10 \mathrm{nM} \mathrm{E}_{2}$ significantly reduced force production in control conditions (Fig. 9). $24 \mathrm{~h}$ exposure to CSE significantly increased force responses to ACh, compared to vehicle which was consistent with our previous contractility studies $[13,14,41]$. Acute exposure of $E_{2}$ did not reduce force responses to ACh for CSE-exposed rings (Fig. 9). 
Fig. 8. CSE increases S-nitrosylation of ER $\alpha$ Human ASM cells exposed for $24 \mathrm{~h}$ to CSE (1\% and $2 \%$ ) were immunoprecipitated for ER $\alpha$ and immunoblotted against anti-S-nitrosocysteine antibody. Aliquots of the cell lysates from the samples were used to detect input ER $\alpha$ and served as a loading control. CSE-exposed ASM cells significantly increased $\mathrm{ER} \alpha$ nitrosylation compared to vehicle. Values represented as means $\pm \mathrm{SE}$ $(n=4) . *$ indicates significant CSE effect compared to vehicle $(P<0.05)$.
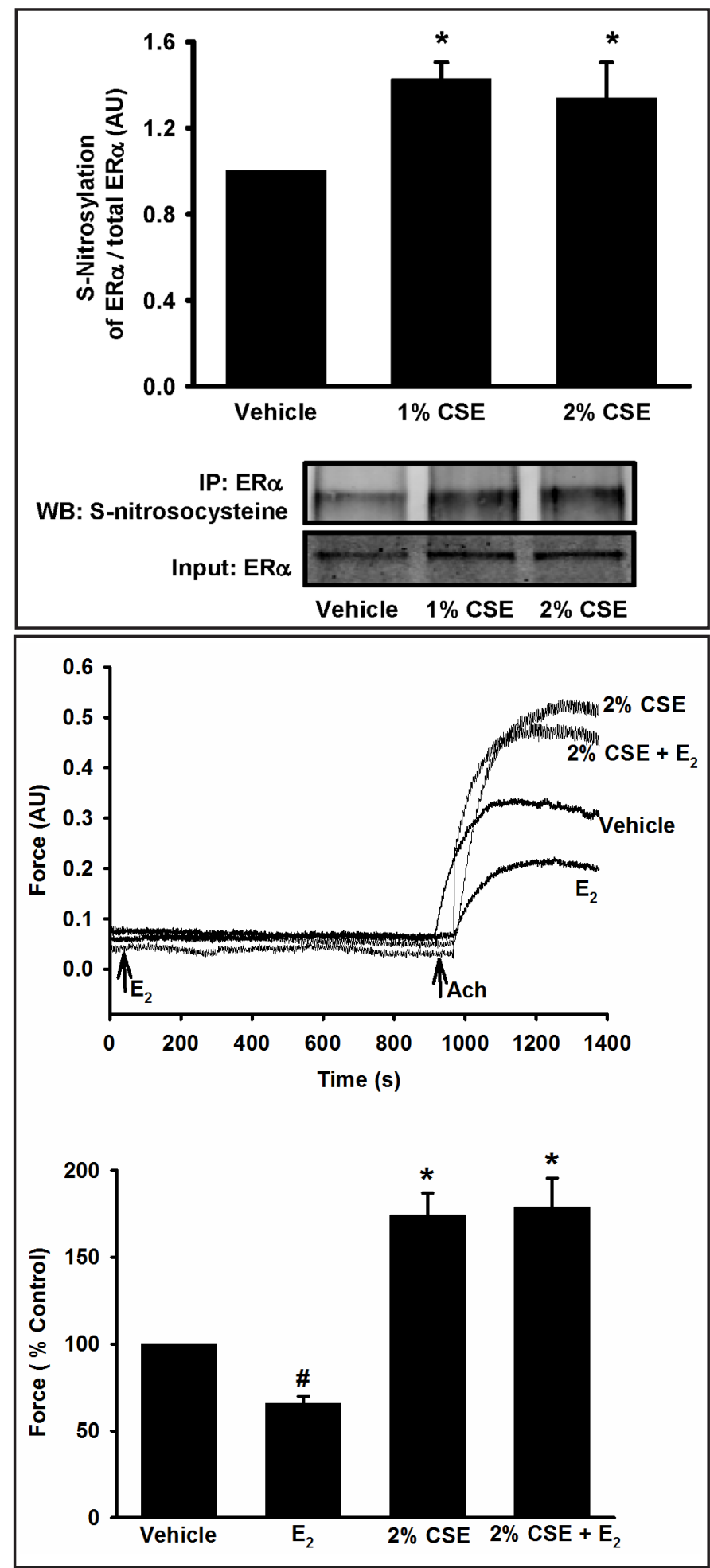

Fig. 9. Effect of CSE and estrogen on human ASM force responses. Epithelium-denuded bronchial rings demonstrated stable force responses to $1 \mu \mathrm{M}$ ACh. 24h exposure to $2 \%$ CSE significantly enhanced force responses, compared to pre-exposure values, as well as time controls. Acute exposure to $\mathrm{E}_{2}$ (20 min) significantly reduced force responses to $\mathrm{ACh}$, but this $\mathrm{E}_{2}$ effect was absent in CSE-exposed bronchial rings. Values represented as means \pm $\mathrm{SE}(\mathrm{n}=4)$ \# indicates significant $\mathrm{E}_{2}$ effect compared to vehicle, *indicates significant CSE effect compared to vehicle and/or $\mathrm{E}_{2}$ group $(P<0.05)$.

\section{Discussion}

In the present study, we demonstrate the detrimental effects of cigarette smoke on estrogen signaling in human ASM. The relevance of this work lies in clinical evidence for a female:male sex ratio of $>1$ in the incidence/frequency of and morbidity/mortality associated with smoking-induced airway and lung diseases [42-49]. In this regard, the conducting 


\section{Cellular Physiology Cell Physiol Biochem 2015;36:1101-1115 \begin{tabular}{l|l} 
and Biochemistry Published online: June 25, 2015 & $\begin{array}{l}\text { Co 2015 S. Karger AG, Basel } \\
\text { www.karger.com/cpb }\end{array}$ \\
\hline
\end{tabular} \\ Sathish et al.: Estrogens, Cigarette Smoke, and Airways}

airways may be more affected in women with greater incidence of asthma and bronchitis, compared to more COPD in men $[48,50,51]$. On the other hand, several studies including our own have shown that estrogens can be bronchodilatory, and thus offer a "protective" role. Therefore, the question arises as to whether such beneficial effects of estrogens are maintained in the presence of CS exposure. We focused on a major structural and functional element of the airway, i.e. ASM, which regulates airway tone, and the effect of CS on estrogeninduced changes in $\left[\mathrm{Ca}^{2+}\right]_{i}$. To our knowledge, this is the first study to establish the influence of CS on acute estrogen effects on $\left[\mathrm{Ca}^{2+}\right]_{\mathrm{i} .}$

\section{Estrogen signaling in the airway}

Estrogen effects can be mediated by two receptors, $\operatorname{ER} \alpha$ and $\operatorname{ER} \beta[6,9]$, acting via classical, genomic mechanisms of altered protein expression/function, or in acute, nongenomic fashion. The vasodilatory effects of estrogens are well-known. Acute exposure to clinically-relevant $\mathrm{E}_{2}$ concentrations $(<10 \mathrm{nM})$ blunts agonist-induced $\left[\mathrm{Ca}^{2+}\right]_{\mathrm{i}}$ responses $[30$, 31]. In coronary artery, [32] carotid artery [33] and aorta [34] estrogens inhibit $\mathrm{Ca}^{2+}$ influx via voltage gated $\mathrm{Ca}^{2+}$ channels. Estrogens may also indirectly decrease influx by modulating membrane potential via $\mathrm{Ca}^{2+}$ activated $\mathrm{K}^{+}\left(\mathrm{BK}_{\mathrm{Ca}}\right)$ channels $[31,52]$. In human platelets, the synthetic estrogen agonist diethylstilbestrol inhibits SOCE [53]. One study in mouse airways sensitized by serum from asthmatic humans demonstrated acute bronchodilation by $\mathrm{E}_{2}$ [10]. Novel data from our group indicate that clinically-relevant concentrations of estrogen normally produce bronchodilation in human airways, by reducing ASM $\left[\mathrm{Ca}^{2+}\right]_{i}[6]$ enhancing NO release by airway epithelium [8] and potentially improving beta-adrenergic signaling [7].

\section{Cigarette Smoke Exposure in the Airway}

Cigarette smoking can exacerbate respiratory disorders such as asthma and bronchitis, which are characterized by airway inflammation and exaggerated airway narrowing (hyperreactivity). There is currently limited but increasing information on this aspect of CSrelated airway disease, ranging from smoke challenge studies in humans and animal models [54-56] to cellular mechanisms involving ASM [13, 14, 41]. However, there is currently little information on sex differences in CS-induced changes in the airway, particularly mechanisms by which CS alters estrogen signaling in ASM. This has important clinical relevance due to increasing rates of female smokers (and exposure to SHS from spouses) and greater numbers of women now diagnosed with chronic obstructive pulmonary disease (COPD) [42, 43], highlighting the importance of the current study.

\section{$\left[\mathrm{Ca}^{2+}\right]_{i}$ Regulation, Estrogen and Cigarette Smoke Effect on ASM}

$\left[\mathrm{Ca}^{2+}\right]_{i}$ and force regulation in ASM has been extensively reviewed $[15-17,57,58]$. $\left[\mathrm{Ca}^{2+}\right]_{i}$ elevation following bronchoconstrictor stimulation involves both sarcoplasmic reticulum (SR) $\mathrm{Ca}^{2+}$ release and plasma membrane $\mathrm{Ca}^{2+}$ influx, $[23,24]$ with the latter occurring via voltage-gated or receptor-operated channels, or due to SOCE following SR $\mathrm{Ca}^{2+}$ depletion $[18-21,36]$. Subsequent decrease in $\left[\mathrm{Ca}^{2+}\right]_{\mathrm{i}}$, and maintenance of $\mathrm{Ca}^{2+}$ homeostasis involves sarcoendoplasmic reticulum $\mathrm{Ca}^{2+}$ ATPase (SERCA), plasma membrane $\mathrm{Ca}^{2+}$ ATPase, and newly-recognized mechanisms such as the bidirectional $\mathrm{Na}^{+} / \mathrm{Ca}^{2+}$ exchange (NCX) $[22,59]$ and mitochondrial $\mathrm{Ca}^{2+}$ buffering $[60,61]$. Only a few studies including our own $[6,8,62]$ have examined ER expression within the airway, especially in humans, and have reported expression of the classical estrogen receptors (ER $\alpha$ and ER $\beta$ ). Additionally, we have previously shown that acute exposure to physiological concentrations of $\mathrm{E}_{2}$ decreases $\left[\mathrm{Ca}^{2+}\right]_{\mathrm{i}}$ response to histamine, an effect reversed by the ER antagonist ICI-182,780 [6]. The inhibition of $\mathrm{Ca}^{2+}$ influx works through several mechanisms, one of which we previously published by inhibiting voltage gated $\mathrm{Ca}^{2+}$ channels through activation of the PKA /cyclic AMP pathway [6]. Here, we provide evidence that inhibition of SOCE [6] by estrogen occurs through alteration in STIM1 phosphorylation.

The present study also demonstrates that CSE reduces intracellular cAMP production which may allow for increased effects of CSE on agonist-induced $\left[\mathrm{Ca}^{2+}\right]_{i^{*}}$ A previous study using 
prenatal lung showed that CS decreases cAMP levels and leads to airway hyperresponsiveness [63]. The cAMP/PKA pathway regulates multiple $\mathrm{Ca}^{2+}$ regulatory mechanisms in human ASM. Our novel data suggest that estrogen-mediated production of cAMP is reduced by CSE exposure leading to increased $\left[\mathrm{Ca}^{2+}\right]_{\mathrm{i}}$ in ASM cells. We also found that CSE exposure substantially enhances expression of both ERs. These interesting data highlight the fact that even with increased ER expression; ER-mediated signaling is significantly blunted with CSE exposure, leading to dysfunctional ER signaling in the airway, as also reflected by impaired downstream cAMP production in human ASM. In this regard, CS may also alter adenylate cyclase expression and activity, an aspect beyond the scope of our study, but a potentially important point for future investigation.

Previous studies suggest that Orai1 and STIM1 (calcium channel and calcium sensor respectively) are key mediators of SOCE [64]. Both Orai1 and STIM1 proteins are molecular constituents of capacitative calcium entry which is activated upon depletion of intracellular $\mathrm{Ca}^{2+}$ stores. Previously, we $[35,36]$ and others $[57,65,66]$ have shown that in vitro exposure to pro-inflammatory cytokines TNF $\alpha$, and IL-13 can increase SOCE response and expression of major SOCE regulatory proteins STIM1 and Orai1 in human ASM. The present study is the first to demonstrate increased expression of STIM1 and Orai1 with CSE exposure. To avoid confounding results due to ASM culture vs. freshly isolated tissues in the expression of STIM1 and Orai1 [67], we confirmed SOCE regulatory protein expression using freshly dissected ASM tissue as well. Additionally, we report the constitutive expression of newly identified protein SARAF $[37,38]$, a negative regulator of SOCE in human ASM cells. Notably, CSE exposure did not change the expression of SARAF, suggesting that inhibition of SOCE may not necessarily be influenced. However due to the increase in STIM1 expression, the ratio of SARAF to STIM1 was significantly reduced. This change in ratio may suggest a propensity for maintained SOCE with CSE exposure, as found in our study. Furthermore, reduced SARAF ratio to STIM1 can lead to increased STIM1 aggregation, as shown in other cell types $[37,38]$ resulting in significantly enhanced SOCE with cigarette smoke exposure.

After ER/SR $\mathrm{Ca}^{2+}$ depletion, STIM1 transforms from a dimer and oligomerizes leading to SOCE activation [68]. Sheridan et al. recently showed that acute exposure to $\mathrm{E}_{2}$ inhibits STIM1 mobility in airway epithelial cells by inhibiting serine phosphorylation of STIM1, thereby reducing SOCE [39]. A consistent finding in our study was is that CSE significantly increased CPA-induced serine phosphorylation of STIM1 in ASM. Thus the inhibitory effect of estrogen on phosphorylation of STIM1 is blunted by CSE, permitting increased SOCE. These data collectively show multiple targets for cigarette smoke-induced SOCE activation and increased $\left[\mathrm{Ca}^{2+}\right]_{\mathrm{i}}$ signaling in human ASM.

\section{Cigarette Smoke Effects on Estrogen Receptors}

Consistent with the idea that on one hand estrogens decrease $\left[\mathrm{Ca}^{2+}\right]_{\mathrm{i}}$ in ASM, while CSE enhances $\left[\mathrm{Ca}^{2+}\right]_{i}$, we expected CSE to reduce ER expression. However, CSE appears to increase especially ER $\alpha$ suggesting that CS exposure results in ER dysfunction. While there may be a myriad of potential mechanisms by which such dysfunction occurs, our observation of increased S-nitrosothiol formation on ER $\alpha$ may be one such pathway, especially given our finding that the observed increase in S-nitrosylation of ER $\alpha$ was disproportionately greater than changes in receptor expression with CSE exposure. The alteration of protein function by S-nitrosylation indicates that nitrosothiols might function as a significant post-translational modification similar to phosphorylation or acetylation $[69,70]$. There has been supporting evidence that possible modification of thiol-containing residues can lead to modulation of $E R \alpha$ function [40]. Furthermore the observed modifications with CSE exposure to ER $\alpha$ may partially involve a decrease in $\mathrm{Ca}^{2+}$ regulatory mechanisms via estrogen. These functional cellular studies were further confirmed by force studies on human bronchial rings where CSE exposure completely blunted the ability of estrogen to acutely reduce force generation.

In summary, clinically-relevant estrogen concentrations significantly decrease $\left[\mathrm{Ca}^{2+}\right]_{\mathrm{i}}$ in ASM, thereby facilitating bronchodilation in human ASM. In contrast, CS which enhances $\left[\mathrm{Ca}^{2+}\right]_{i}$, blunts the effect of estrogen. Our studies suggest that CSE influences estrogen's 


\begin{tabular}{|c|c|c|}
\hline Cellular Physiology & Cell Physiol Biochem 2015;36:1101-1115 & \\
\hline and Biochemistry & $\begin{array}{l}\text { DoI: } 10.1159 / 000430282 \\
\text { Published online: June } 25,2015\end{array}$ & $\begin{array}{l}\text { O) } 2015 \mathrm{~S} \text {. Karger AG, Basel } \\
\text { www.karger.com/cpb }\end{array}$ \\
\hline
\end{tabular}

effects via $\mathrm{Ca}^{2+}$ entry. This happens in spite of CS increasing estrogen receptor expression, and by inhibiting ER-mediated signaling

\section{Disclosure Statement}

No conflicts of interest.

\section{Acknowledgments}

This research was supported by grants from the Flight Attendants Medical Research Institute (FAMRI; Sathish, Pabelick), NIH grant HL088029 and HL088029-S1 (Prakash) and by the Department of Anesthesiology (Pabelick, Prakash).

\section{References}

1 Sopori M: Effects of cigarette smoke on the immune system. Nat Rev Immunol 2002;2:372-377.

2 Jaakkola MS, Jaakkola JJK: Assessment of exposure to environmental tobacco smoke. Eur Respir J 1997;10:2384-2397.

3 Gold DR, Wang X, Wypij D, Speizer FE, Ware JH, Dockery DW: Effects of cigarette smoking on lung function in adolescent boys and girls. N Engl J Med 1996;335:931-937.

4 Hecht SS: Progress and challenges in selected areas of tobacco carcinogenesis. Chem Res Toxicol 2007;21:160-171.

5 Sathish V, Martin YN, Prakash YS: Sex steroid signaling: Implications for lung diseases. Pharmacol Ther 2015;150:94-108.

6 Townsend EA, Thompson MA, Pabelick CM, Prakash YS: Rapid effects of estrogen on intracellular ca $\mathrm{ca}^{2+}$ regulation in human airway smooth muscle. Am J Physiol Lung Cell Mol Physiol 2010;298:L521-530.

7 Townsend EA, Sathish V, Thompson MA, Pabelick CM, Prakash YS: Estrogen effects on human airway smooth muscle involve camp and protein kinase a. Am J Physiol Lung Cell Mol Physiol 2012;303:L923-928.

8 Townsend EA, Meuchel LW, Thompson MA, Pabelick CM, Prakash YS: Estrogen increases nitric-oxide production in human bronchial epithelium. J Pharmacol Exp Ther 2011;339:815-824.

9 Heldring N, Pike A, Andersson S, Matthews J, Cheng G, Hartman J, Tujague M, Strom A, Treuter E, Warner M, Gustafsson JA: Estrogen receptors: How do they signal and what are their targets. Physiol Rev 2007;87:905-931.

10 Dimitropoulou C, White RE, Ownby DR, Catravas JD: Estrogen reduces carbachol-induced constriction of asthmatic airways by stimulating large-conductance voltage and calcium-dependent potassium channels. Am J Respir Cell Mol Biol 2005;32:239-247.

11 Couse JF, Lindzey J, Grandien K, Gustafsson JA, Korach KS: Tissue distribution and quantitative analysis of estrogen receptor-alpha (er alpha) and estrogen receptor-beta (er beta) messenger ribonucleic acid in the wild-type and er alpha-knockout mouse. Endocrinol 1997;138:4613-4621.

12 Aravamudan B, Kiel A, Freeman M, Delmotte P, Thompson M, Vassallo R, Sieck GC, Pabelick CM, Prakash YS: Cigarette smoke-induced mitochondrial fragmentation and dysfunction in human airway smooth muscle. Am J Physiol Lung Cell Mol Physiol 2014;306:L840-854.

13 Sathish V, Vanoosten SK, Miller BS, Aravamudan B, Thompson MA, Pabelick CM, Vassallo R, Prakash YS: Brain-derived neurotrophic factor in cigarette smoke-induced airway hyperreactivity. Am J Respir Cell Mol Biol 2013;48:431-438. 
14 Chiba Y, Ueno A, Shinozaki K, Takeyama H, Nakazawa S, Sakai H, Misawa M: Involvement of rhoa-mediated $\mathrm{ca}^{2+}$ sensitization in antigen-induced bronchial smooth muscle hyperresponsiveness in mice. Respir Res 2005;6:4.

15 Prakash YS: Airway smooth muscle in airway reactivity and remodeling: What have we learned? Am J Physiol Lung Cell Mol Physiol 2013;305:L912-933.

16 Sanderson MJ, Delmotte P, Bai Y, Perez-Zogbhi JF: Regulation of airway smooth muscle cell contractility by $\mathrm{ca}^{2+}$ signaling and sensitivity. Proc Am Thorac Soc 2008;5:23-31.

17 Sanders KM: Invited review: Mechanisms of calcium handling in smooth muscles. J Appl Physiol 2001;91:1438-1449.

18 Worley JF, Kotlikoff MI: Dihydropyridine-sensitive single calcium channels in airway smooth muscle cells. Am J Physiol 1990;259:L468-L480.

19 Ay B, Prakash YS, Pabelick CM, Sieck GC: Store-operated $\mathrm{Ca}^{2+}$ entry in porcine airway smooth muscle. Am J Physiol Lung Cell Mol Physiol 2004;286:L909-L917.

20 Parekh AB, Putney JW Jr: Store-operated calcium channels. Physiol Rev 2005;85:757-810.

21 Putney JW Jr: Recent breakthroughs in the molecular mechanism of capacitative calcium entry (with thoughts on how we got here). Cell Calcium 2007;42:103-110.

22 Sathish V, Delmotte PF, Thompson MA, Pabelick CM, Sieck GC, Prakash YS: Sodium-calcium exchange in intracellular calcium handling of human airway smooth muscle. PLoS One 2011;6:e23662.

23 Sathish V, Leblebici F, Kip SN, Thompson MA, Pabelick CM, Prakash YS, Sieck GC: Regulation of sarcoplasmic reticulum $\mathrm{ca}^{2+}$ reuptake in porcine airway smooth muscle. Am J Physiol Lung Cell Mol Physiol 2008;294:L787-796.

24 Sathish V, Thompson MA, Bailey JP, Pabelick CM, Prakash YS, Sieck GC: Effect of proinflammatory cytokines on regulation of sarcoplasmic reticulum $\mathrm{Ca}^{2+}$ reuptake in human airway smooth muscle. Am J Physiol Lung Cell Mol Physiol 2009;297:L26-34.

25 Sathish V, Yang B, Meuchel LW, VanOosten SK, Ryu AJ, Thompson MA, Prakash YS, Pabelick CM: Caveolin-1 and force regulation in porcine airway smooth muscle. Am J Physiol Lung Cell Mol Physiol 2011;300:L920929.

26 Blue ML, Janoff A: Possible mechanisms of emphysema in cigarette smokers. Release of elastase from human polymorphonuclear leukocytes by cigarette smoke condensate in vitro. Am Rev Respir Dis 1978;117:317-325.

27 Smelter DF, Sathish V, Thompson MA, Pabelick CM, Vassallo R, Prakash YS: Thymic stromal lymphopoietin in cigarette smoke-exposed human airway smooth muscle. J Immunol 2010;185:3035-3040.

28 Sathish V, Xu A, Karmazyn M, Sims SM, Narayanan N: Mechanistic basis of differences in $\mathrm{Ca}^{2+}$-handling properties of sarcoplasmic reticulum in right and left ventricles of normal rat myocardium. Am J Physiol Heart Circ Physiol 2006;291:H88-96.

29 Aesif SW, Kuipers I, van der Velden J, Tully JE, Guala AS, Anathy V, Sheely JI, Reynaert NL, Wouters EF, van der Vliet A, Janssen-Heininger YM: Activation of the glutaredoxin-1 gene by nuclear factor kappab enhances signaling. Free Radic Biol Med 2011;51:1249-1257.

30 Miller VM, Duckles SP: Vascular actions of estrogens: Functional implications. P Pharmacol Rev 2008;60:210-241.

31 Prakash YS, Togaibayeva AA, Kannan MS, Miller VM, Fitzpatrick LA, Sieck GC: Estrogen increases ca ${ }^{2+}$ efflux from female porcine coronary arterial smooth muscle. Am J Physiol 1999;276:H926-934.

32 Moritz A, Radtke OA, Gust R, Glusa E, Pertz HH: Characterisation of the relaxant response to raloxifene in porcine coronary arteries. Eur J Pharmacol 2006;545:153-160.

33 Salom JB, Burguete MC, Perez-Asensio FJ, Centeno JM, Torregrosa G, Alborch E: Acute relaxant effects of 17-beta-estradiol through non-genomic mechanisms in rabbit carotid artery. Steroids 2002;67:339-346.

34 Seeger H, Mueck AO, Oettel M, Schwarz S, Lippert TH: Calcium antagonistic effect of 17 alpha-estradiol derivatives: In vitro examinations. Gynecol Endocrinol 1999;13:246-248.

35 Sieck GC, White TA, Thompson MA, Pabelick CM, Wylam ME, Prakash YS: Regulation of store-operated Ca ${ }^{2+}$ entry by cd38 in human airway smooth muscle. Am J Physiol Lung Cell Mol Physiol 2008;294:L378-385.

36 Sathish V, Abcejo AJ, Thompson MA, Sieck GC, Prakash YS, Pabelick CM: Caveolin-1 regulation of storeoperated $\mathrm{ca}^{2+}$ influx in human airway smooth muscle. Eur Resp J 2012;40:470-478.

37 Palty R, Raveh A, Kaminsky I, Meller R, Reuveny E: Saraf inactivates the store operated calcium entry machinery to prevent excess calcium refilling. Cell 2012;149:425-438. 
38 Jha A, Ahuja M, Maleth J, Moreno CM, Yuan JP, Kim MS, Muallem S: The stim1 ctid domain determines access of saraf to soar to regulate orai1 channel function. J Cell Biol 2013;202:71-79.

39 Sheridan JT, Gilmore RC, Watson MJ, Archer CB, Tarran R: 17 $\beta$-estradiol inhibits phosphorylation of stromal interaction molecule 1 (stim1) protein: Implication for store-operated calcium entry and chronic lung diseases. J Biol Chem 2013;288:33509-33518.

40 Garban HJ, Marquez-Garban DC, Pietras RJ, Ignarro LJ: Rapid nitric oxide-mediated s-nitrosylation of estrogen receptor: Regulation of estrogen-dependent gene transcription. Proc Natl Acad Sci U S A 2005;102:2632-2636.

41 Ye H, Ma WL, Yang ML, Liu SY, Wang DX: Effect of chronic cigarette smoking on large-conductance calciumactivated potassium channel and kv1.5 expression in bronchial smooth muscle cells of rats. Sheng Li Xue Bao 2004;56:573-578.

42 Mannino DM, Homa DM, Akinbami LJ, Ford ES, Redd SC: Chronic obstructive pulmonary disease surveillance--united states, 1971-2000. Respiratory care 2002;47:1184-1199.

43 Troisi RJ, Speizer FE, Rosner B, Trichopoulos D, Willett WC: Cigarette smoking and incidence of chronic bronchitis and asthma in women. Chest 1995;108:1557-1561.

44 Bjornson CL, Mitchell I: Gender differences in asthma in childhood and adolescence. J Gend Specif Med 2000;3:57-61.

45 Caracta CF: Gender differences in pulmonary disease. Mt Sinai J Med 2003;70:215-224.

46 Carey MA, Card JW, Voltz JW, Arbes SJ, Jr., Germolec DR, Korach KS, Zeldin DC: It's all about sex: Gender, lung development and lung disease. Trends Endocrinol Metab 2007;18:308-313.

47 Jensen-Jarolim E, Untersmayr E: Gender-medicine aspects in allergology. Allergy 2008;63:610-615.

48 Melgert BN, Ray A, Hylkema MN, Timens W, Postma DS: Are there reasons why adult asthma is more common in females? Curr Allergy Asthma Rep 2007;7:143-150.

49 Sin DD, Cohen SB, Day A, Coxson H, Pare PD: Understanding the biological differences in susceptibility to chronic obstructive pulmonary disease between men and women. Proc Am Thorac Soc 2007;4:671-674.

50 Redline S, Gold D: Challenges in interpreting gender differences in asthma. Am J Respir Crit Care Med 1994;150:1219-1221.

51 Schatz M, Camargo CA Jr: The relationship of sex to asthma prevalence, health care utilization, and medications in a large managed care organization. Ann Allergy Asthma Immunol 2003;91:553-558.

52 Tep-areenan P, Kendall DA, Randall MD: Mechanisms of vasorelaxation to testosterone in the rat aorta. Eur J Pharmacol 2003;465:125-132.

53 Zakharov SI, Smani T, Dobrydneva Y, Monje F, Fichandler C, Blackmore PF, Bolotina VM: Diethylstilbestrol is a potent inhibitor of store-operated channels and capacitative $\mathrm{Ca}^{2+}$ influx. Mol Pharmacol 2004;66:702707.

54 Stampfli MR, Anderson GP: How cigarette smoke skews immune responses to promote infection, lung disease and cancer. Nat Rev Immunol 2009;9:377-384.

55 Omini C, Hernandez A, Zuccari G, Clavenna G, Daffonchio L: Passive cigarette smoke exposure induces airway hyperreactivity to histamine but not to acetylcholine in guinea-pigs. Pulm Pharmacol 1990;3:145150.

56 Wu ZX, Zhou D, Chen G, Lee LY: Airway hyperresponsiveness to cigarette smoke in ovalbumin-sensitized guinea pigs. Am J Respir Crit Care Med 2000;161:73-80.

57 Jude JA, Wylam ME, Walseth TF, Kannan MS: Calcium signaling in airway smooth muscle. Proc Am Thorac Soc 2008;5:15-22.

58 Hirota S, Helli P, Janssen LJ: Ionic mechanisms and $\mathrm{Ca}^{2+}$ handling in airway smooth muscle. Eur Respir J 2007;30:114-133.

59 Hirota S, Janssen LJ: Store-refilling involves both l-type calcium channels and reverse-mode sodiumcalcium exchange in airway smooth muscle. Eur Respir J 2007;30:269-278.

60 Delmotte P, Yang B, Thompson MA, Pabelick CM, Prakash YS, Sieck GC: Inflammation alters regional mitochondrial $\mathrm{Ca}^{2+}$ in human airway smooth muscle cells. Am J Physiol Cell Physiol 2012;303:C244-256.

61 Dai J, Kuo KH, Leo JM, van Breemen C, Lee CH: Rearrangement of the close contact between the mitochondria and the sarcoplasmic reticulum in airway smooth muscle. Cell Calcium 2005;37:333-340.

62 Catley MC, Birrell MA, Hardaker EL, de Alba J, Farrow S, Haj-Yahia S, Belvisi MG: Estrogen receptor beta: Expression profile and possible anti-inflammatory role in disease. J Pharmacol Exp Ther 2008;326:83-88. 


\section{Cellular Physiology Cell Physiol Biochem 2015;36:1101-1115

and Biochemistry

63 Singh SP, Barrett EG, Kalra R, Razani-Boroujerdi S, Langley RJ, Kurup V, Tesfaigzi Y, Sopori ML: Prenatal cigarette smoke decreases lung camp and increases airway hyperresponsiveness. Am J Respir Crit Care Med 2003;168:342-347.

64 DeHaven WI, Jones BF, Petranka JG, Smyth JT, Tomita T, Bird GS, Putney JW Jr: Trpc channels function independently of stim1 and orai1. J Physiol 2009;587:2275-2298.

65 Jude JA, Solway J, Panettieri RA, Jr., Walseth TF, Kannan MS: Differential induction of cd38 expression by tnfa in asthmatic airway smooth muscle cells. Am J Physiol Lung Cell Mol Physiol 2010;299:L879-890.

66 Jude JA, Panettieri RA Jr, Walseth TF, Kannan MS: Tnf-alpha regulation of cd38 expression in human airway smooth muscle: Role of map kinases and NF-kappab. Adv Exp Med Biol 2011;691:449-459.

67 Trebak M: Stim/orai signalling complexes in vascular smooth muscle. J Physiol 2012;590:4201-4208.

68 Liou J, Fivaz M, Inoue T, Meyer T: Live-cell imaging reveals sequential oligomerization and local plasma membrane targeting of stromal interaction molecule 1 after $\mathrm{Ca}^{2+}$ store depletion. Proc Natl Acad Sci U S A 2007;104:9301-9306.

69 Stamler JS, Simon DI, Osborne JA, Mullins ME, Jaraki O, Michel T, Singel DJ, Loscalzo J: S-nitrosylation of proteins with nitric oxide: Synthesis and characterization of biologically active compounds. Proc Am Thorac Soc 1992;89:444-448.

70 Marshall HE, Hess DT, Stamler JS: S-nitrosylation: Physiological regulation of nf-kb. Proc Am Thorac Soc 2004;101:8841-8842. 